\title{
Allergy reactions to insulin : effects of continuous subcutaneous insulin infusion and insulin analogues
}

\author{
R P Radermecker, A J Scheen
}

Short title : Insulin allergy, insulin analogues, CSII

Address for correspondence :

Régis P. Radermecker, Division of Diabetes, Nutrition and Metabolic Disorders, Department of Medicine, CHU Sart Tilman, University of Liège, B-4000 Liège, Belgium

Phone : 32-4-3667238

Fax : 32-4-3667068

Email : regis.radermecker@ulg.ac.be

\section{SUMMARY}

The purification of animal insulin preparations and the use of human recombinant insulin have markedly reduced the incidence but not completely suppressed the occurrence of insulin allergy manifestations. Advances in technologies concerning the mode of delivery of insulin, i.e. continuous subcutaneous insulin infusion (CSII), and the use of insulin analogues, resulting from the alteration in the amino acid sequence of the native insulin molecule, may influence the immunogenicity and antigenicity of native insulin. Instead of increasing allergy reactions, CSII has been reported to represent a successful alternative treatment in diabetic patients presenting local or generalized allergy to insulin or other components (zinc, protamine) of conventional treatment. Most recent reports concern CSII-treated patients using short-acting insulin analogues (essentially insulin lispro), although the precise role of these insulin analogues remains unclear as allergy to 
them has also been described. Finally, data on antigenicity and immunogenicity of long-acting insulin analogues (glargine, detemir), which may mimic the basal insulin delivery with CSII, remain scarce at present time.

Key-words : CSII - Diabetes - Insulin allergy - Insulin hypersensitivity - Insulin pump - Insulin analogues 


\section{Introduction}

Continuous subcutaneous insulin infusion (CSII), also called insulin pump therapy, was introduced in the 1970s and was proven to be superior on multiple daily insulin injections in a recent meta-analysis of 12 randomised controlled trials comparing the two treatment modalities [2]. Recent data showed that CSII with short-acting insulin analogues (insulin lispro, insulin aspart) provides better control of postprandial hyperglycaemia and further reduced risk of hypoglycaemia, leading to a significant improvement in glycated haemoglobin (HbA1c) and quality of life [3,4]. Therefore, short-acting insulin analogues are now considered as the first choice for CSII therapy [5,6]. In addition, this approach may offer new possibilities in the management of allergy to human insulin.

Soon after the introduction of insulin in the 1920s, clinicians became aware of the immunological complications and skin manifestations that result from reaction to its therapeutic use [7]. Animal (beef, pork) insulins are foreign proteins and have been implicated as allergens, with a much higher skin reactions to beef insulin than to porcine insulin. In addition, noninsulin components of insulin preparations may also react as allergens, such as various impurities (“dirty insulin”), preservatives (metacresol) or agents to prolong action (zinc, protamine) $[8,9]$. Primary allergy to recombinant human insulin has also been described, although the prevalence of hypersensitivity reactions (mostly localised to the injection site and more exceptionally generalised) has dramatically decreased from as many as 50-60 \% in the 1950-1960s $[10,11]$ to less than $1-3 \%$ in the late 1990s [12-15]. However, the current prevalence of such insulin allergy reactions is not precisely known among the diabetic population.

Whereas clinical allergy has become a less-frequent observation, new modalities of insulin delivery may magnify its propensity. For instance, continued use of subcutaneous insulin-infusion pumps raises the important issue of stability of insulin within the delivery system as insulin aggregates may promote insulin hypersensitivity reactions [16]. Furthermore, insulin analogues, resulting from a modified sequence of amino acids of recombinant human insulin, may present new epitopes for recognition by the immune system and thus potentially alter the antigenicity and immunogenicity of insulin in diabetic patients [17-19]. However, as previously suggested [16], the development of physically stable insulin monomers (thus reducing the risk of insulin aggregates) may further decrease the clinical incidence of cutaneous insulin allergy as compared to human regular insulin and minimize the complications associated with insulininfusion therapy. Interestingly, insulin desensitisation with CSII delivering insulin lispro has been reported in several diabetic patients, suggesting that the insulin pump and short-acting insulin may be useful as an alternative treatment in insulin allergy [20].

The present review aims at describing the effects of CSII and/or short-acting insulin analogues (lispro, aspart) on insulin allergy, i.e. localized and more exceptionally generalized manifestations related to insulin hypersensitivity. As new long-acting insulin analogues (glargine, detemir) are able to provide a better basal insulin delivery as compared to NPH insulin and thus may be considered as an alternative to CSII [21,22], recent, albeit scarce, data concerning allergy reactions to these analogues or attempts of insulin desensitization with them will be also briefly summarized.

\section{Hypersensitivity to insulin : brief overview}


Insulin injected into the subcutaneous tissue of diabetic patients can elicit various reactions from the immune system (Figure 1) $[9,23,24]$. Although the frequency of insulin allergy has been reduced with the present availability of high purification technology and with the use of human insulin, reactions varying in severity from mild discomfort to life-threatening still occur in 0.1 to $3.0 \%$ of patients receiving human insulin [13,15,25,26]. Three types of allergic reactions to human insulin have been described [14,27]. Type I immediate hypersensitivity reactions is by far the commonest. This is an IgE dependent reaction that is mediated by the release of vaso-active substances mainly from basophiles and mast cells. Symptoms start at the site of injection with swelling, erythema and itching, and may progress to a generalised reaction, ranging in severity from simple urticaria to anaphylaxis. Symptoms usually resolve after one hour. The reactions typically occur one week after initiation of therapy and in patients who have restarted insulin treatment after a therapeutic gap. Sometimes, biphasic reactions occur, with an initial wheal-flare reaction, followed by a late-phase peaking at 4-6 hours and lasting usually less than 24 hours. However, induration at the injection site may last longer, occasionally several days. These delayed reactions are IgGmediated and cell-mediated, characterized by a local mononuclear infiltration. Type III hypersensitivity (Arthus type) represents local insulin-antibody complex reactions that result in complement fixation and leukocyte attraction with resultant inflammatory response. This serum sickness type is very rare with insulin and is mediated by IgG antibodies. Skin reactions involve small, localized subdermal, tenderness and painful non-erythematous nodules with central hematomas at injection sites, occurring around 6-8 hours after the insulin injection and lasting for 48 hours [28]. Type IV reaction corresponds to tuberculin-like T lymphocyte-mediated delayed hypersensitivity. The cutaneous nodules could be distinguished from those of the type III hypersensitivity reactions as they occur usually 24 hours or more after the insulin injection, lasting for 4-7 days.

Confirmation of the allergic nature of skin lesions (which might also be due to incorrect injection technique) can be obtained by intradermal testing using a $1: 10$ dilution of the insulin preparation [26]. Appearance of a lesion within 60 minutes of injection indicates immediate hypersensitivity, whereas delayed hypersensitivity would be shown by a response between 2 and 24 hours [27].

Highly purified and recombinant insulin preparations are virtually free of protein contaminants, an advantage that has undoubtedly contributed to the decreasing prevalence of insulin allergies. Currently, allergic reactions to insulin preparations are induced not only by the insulin molecule, especially when the tertiary structure of insulin is altered, but also by the presence of non-protein contaminants, or pharmaceutical additives, such as protamine sulphate, zinc or metacresol [12, 29]. Allergic reactions to protamine sulphate are common and should not be ignored. They can be easily detected with positive intradermal skin test reactions to protamine sulphate [26, 30] and they can be managed by switching NPH insulin preparations to other lente insulin preparations free of protamine. Finally, insulin-injection-site reactions associated with type 1 latex allergy have also been reported in exceptional cases with type 1 diabetes [31-33].

Local skin reactions are usually short-lived and resolve spontaneously within a few weeks despite continuation of insulin [14]. A standardized investigative procedure of suspected insulin preparation allergy was associated with relief of symptoms in $>90 \%$ in a retrospective series of 22 cases [26]. If the skin reactions persist longer than several weeks, a number of potential options may be considered, including changing insulin to a less allogenic type (i.e. insulin analogues) and /or varying the insulin delivery mode (i.e. CSII). 
These new options challenge the classical approach using desensitization procedure, a tolerance induction technique has been described to be successful in some cases, but is rather fastidious to implement in clinical practice [13,15,25,26].

\section{CSII AND INSULIN ALLERGY}

CSII raises the important issue of stability of insulin within the delivery system [16], because of prolonged contact with plastic reservoirs and tubing, higher-temperature exposure, and possible agitation as described in presence of a constant pumping motion [34]. Possible interaction between plastic catheter tubings and regular insulin preparations used for CSII (35) and problem of insulin compatibility with polymer materials used in external pump infusion systems [36] have also pointed out. Despite potential changes in the tertiary structure of insulin, no increase in the incidence of allergic reactions to insulin was described in CSII-treated patients. Only contact dermatitis has been reported in some diabetic patients resulting from the presence of acrylates, epoxy resin, components of glue or nickel needle in the insulin pump infusion sets [37].

CSII has been proposed to reduce allergy to insulin when injected conventionally [20]. Indeed, most desensitisation protocols involve the frequent administration of small and incrementally increasing doses of insulin in order to obtain low constant blood levels that gradually increase to therapeutic levels. Continuous delivery may be used to avoid repeated injections, and thus CSII would be an ideal method of desensitisation. Furthermore, if necessary, dermal hypersensitivity to insulin may be improved by simultaneous infusion of small amounts of corticosteroids with insulin in patients experiencing these reactions [38].

The successful treatment with an insulin pump delivering regular insulin was first reported in a young girl with type 1 diabetes who, within two months of insulin therapy, developed generalised allergy due to both zinc and protamine in insulin preparation [39]. The first report of management of true insulin allergy using CSII was published in 1988 [40]. Three years after beginning insulin therapy with beefpork insulin, a 34-yr-old, nonatopic woman developed urticaria. Laboratory findings excluded the usual etiologies of generalized urticaria and/or pruritus, but specific IgE antibodies against bovine and porcine insulins were found. Antihistaminic treatment and desensitisation with high-purified porcine and human insulin were attempted without improvement. Therefore, CSII with human regular insulin was started. With this therapeutic regimen a rapid improvement of subjective symptomatology was observed with the gradual disappearance of allergic reactions over 2 months. Interestingly, local allergic reactions in injection sites recurred one year later, when the patient again underwent conventional insulin therapy. Presence of specific IgE against porcine, bovine and human insulins was confirmed. The patient was again treated with CSII with a rapid disappearance of allergic reactions. This therapeutic attempt was based on the supposition that the infusion of insulin microdoses at a continuous basal rate could represent an effective desensitisation method. One proposed mechanism was that CSII is able to maintain the mast cells chronically degranulated in insulin-infusion areas and so block the immunological reaction liable to allergic manifestations [40].

Despite this initial favourable report, the use of CSII delivering human regular insulin in diabetic patients with insulin allergy when treated with conventional injection therapy remained exceptional, as only one single case has been described with continuous delivery of human insulin [41]. A 63-year-old insulin-dependent diabetic woman was hospitalised with itchy skin wheals at the injection sites of 
human insulin. After intradermal skin testing was performed, the erythema and wheal were recorded immediately, and the increased titer of human insulin-specific IgE antibody indicated immediate-type allergy against human insulin. Administration of an anti-allergic drug or desensitisation for human insulin every two hours was not effective. In contrast, after CSII therapy was performed, both itching and wheal disappeared. The authors concluded that the process may be a desensitisation through CSII and suggested that CSII may be useful in the treatment for human insulin allergy [41].

Several recent reports further confirmed the potential interest of CSII in the treatment of insulin allergy, but all concerned patients treated with pump delivering short-acting insulin analogues (vide infra).

\section{Insulin analogues and insulin allergy}

To develop insulin analogues with more desirable pharmacokinetic properties, alterations have been made in the amino acid sequence of human insulin. The human insulin analogues lispro and aspart are produced by interchange of the positions of the amino acids B28-Pro and B29-Lys, and replacing B28-Pro with Asp, respectively. These changes cause rapid dissociation of hexamers into monomers spontaneously, resulting in rapid absorption, action, and degradation of insulin [5,6]. Ideally, insulin analogues should neither produce an immune response that results in local or systemic allergic manifestations in excess of those of human insulin preparations nor generate antibodies that bind to and neutralize insulin. However, insulin analogues may present new epitopes for recognition by the immune system. Interestingly, in vitro data suggested that insulin aggregates rather than native monomers cause cutaneous allergy and that antigenicity of insulin preparations correlates with the relative concentration of aggregates [16]. Structural changes leading to insulin lispro and insulin aspart (monomeric insulins) were initially reported to result in decreased immunogenicity in in vivo studies [17,18]. However, recent studies with both insulin lispro [42,43] or insulin aspart [44] rather reported results supporting similar immunogenicity of the two analogues when compared to human regular insulin. A multinational, multicentre combination of controlled and non-controlled, open-label studies of 4.5 years' duration showed that the incidence of insulin allergy in patients receiving subcutaneous administration of insulin lispro was not different from that in patients treated with recombinant regular human insulin [42]. Lindholm et al [44] reported that insulin aspart caused allergic reactions as frequently as regular human insulin, although there was no consistent relationship between antibody formation and adverse events.

Nevertheless, insulin lispro or insulin aspart analogues may be less antigenic for people with insulin allergy as they do not aggregate to form polymers [16]. Anecdotal reports suggested local and generalized allergy to human insulin could be successfully treated with insulin lispro [45-49] or with insulin aspart [49-51]. In the series of 22 cases published by Bodtger et al [26], 5 patients were treated with insulin analogues, among whom 3 with a clear success and 2 with partial improvement. Successful treatment of insulin allergy in a 1-yearold infant with neonatal diabetes by lispro and glargine insulin was reported recently [52]. However, insulin allergy has also been reported with insulin lispro [53-55] and with insulin aspart [19,56]. One case of insulin allergy to insulin aspart, associated with insulin resistance, occurred in a patient with lung cancer and was considered as a paraneoplastic syndrome based on interleukin-6 secretion [56]. In a recent review of the literature focusing on systematic allergy to insulin, a series of 11 cases of lispro or aspart sensitization were reported, 
demonstrating that clinical allergy to these new insulin analogues exists as well [57]. Insulin allergy was not always treated successfully with insulin aspart [55,58]. Interestingly, one case report described the positive effect of using a short-acting insulin analogue instead of crystalline insulin in a patient already on CSII therapy [59]. This 22-year-old woman with type 1 diabetes developed pruritus and erythema at the injection site three months after starting treatment with crystalline insulin given through an infusion pump. Following various attempts of desensitisation, the short-acting insulin analogue lispro was used. It was first administered to increasing doses using classical subcutaneous injections. Urticaria disappeared within three days, and insulin lispro could be administered by pump infusion with no recurrence of urticaria over a follow-up of more than 18 months. The favourable course of this severe insulin allergy emphasizes the potential interest of insulin lispro in patients with insulin allergy, and opens new prospects in combining CSII and short-acting insulin analogues.

New long-acting insulin analogues such as insulin glargine and insulin detemir offer the potential advantage of a better basal insulin coverage over a 24-h period as compared to insulin NPH, with less hypoglycaemic events [5,6]. Therefore, once-daily dose of insulin glargine has been proposed as an alternative to CSII as it provides more effective glycaemic control over 24 hours as compared to intermediate insulin NPH [21,22]. Two case reports [52,60] showed that insulin glargine can resolve a generalized allergy to human insulin in type 1 diabetic patients. The first case was a 45-year-old type 1 diabetic Japanese man with generalized allergy to human insulin who was successfully treated with insulin glargine [60]. Although the precise mechanism to induce the tolerance across other insulins remains unclear, this is the first report to demonstrate that insulin glargine allows generalized insulin allergy to be overcome. The other case concerns a 1-year-old infant with neonatal diabetes [52]. In this infant, intradermal tests confirmed the insulin allergy to different kinds of insulin and attempts of treatment with antiallergic drugs and gradual insulin desensitization with low doses of regular insulin were not successful. As skin tests were negative with glargine insulin, treatment with this new basal insulin was initiated without any allergic reaction and an adequate glycaemic control over a 6-month period. However, glargine insulin can not always be considered as an alternative in insulin allergy. Indeed, the first report of allergy with glargine insulin has been described in an 81-year-old man with type 2 diabetes [61]. In that particular case, skin-prick tests were positive for human and porcine insulin as well as for lispro and glargine insulin, but not for aspart insulin. Therefore, the patient was treated successfully with CSII of aspart with no local reaction and gradually improved metabolic control. Another preliminary report described the case of a 20-year-old diabetic woman, who presented delayed local manifestations after glargine injection, with negative intradermal reaction to all insulin preparations tested, except for a weak response for glargine [62]. A 60-year type 2 diabetic patient with allergy reactions to all kinds of human insulin and short-acting insulin analogues, showed similar cutaneous reactions to glargine as to other insulin preparations [63]. Finally, Castera et al [57] described a case of allergy to all kinds of insulin commercially available in France at that time, lispro, aspart and glargine insulin included. However, they did not test the new rapid analogue glulisine and the new long acting analogue detemir. Almost no information is available in literature concerning the allergenicity of these new insulin analogues or their use in the treatment of insulin allergy. Nevertheless, a first case of type III allergy to the new long-acting insulin analogue detemir has been recently reported in a 31-year old man with type 1 diabetes for 20 years without any history of allergy, especially to previous insulin preparations, including insulin glargine and insulin aspart [64]. Thus, contradictory 
observations are available in the literature regarding the potential interest or the absence of deleterious effect of the new long-acting insulin analogues glargine and detemir as far as insulin allergy is concerned.

\section{CSII with insulin analogues and insulin allergy}

As CSII with regular insulin has proven its efficacy to treat insulin allergy and as the use of insulin analogues could also reduce insulin allergy, one may expect that the combination of short-acting insulin analogue and CSII should be the best way to manage patients with insulin allergy [20]. One study demonstrated that potency and purity of insulin lispro were practically unchanged after 2 days of pumping in two different insulin infusion systems when syringes and catheters are replaced at 48-h intervals [65]. A recent study confirmed appropriate physiochemical stability of insulin lispro for use in various pump devices [66].

Ten case reports have been recently published demonstrating the efficacy of CSII delivering short-acting insulin analogues (8 with insulin lispro, 2 with insulin aspart) in patients with various types of diabetes presenting local cutaneous insulin reactions with conventional insulin treatment. They concerned various types of diabetic patients, i.e. a child with type 1 diabetes, two elderly patient with insulinrequiring type 2 diabetes, two middle-age patients with type 2 diabetes, four adults with type 1 diabetes of various duration and a woman with gestational diabetes. These ten cases that illustrate successful desensitisation using CSII delivering insulin lispro or insulin aspart will be briefly described (Table 1). Such detailed description of individual cases will allow emphasize the heterogeneity of demographic characteristics, clinical presentation, type of insulin responsible of allergy and attempts of management before trying CSII and short-acting insulin analogue.

In a 5-year-old girl with type 1 diabetes and insulin allergy, successful desensitisation could be obtained using an insulin pump and insulin lispro whereas additional oral antihistamine and co-administration of subcutaneous dexamethasone along with human insulin previously failed to control her symptoms [67]. In a 79-year-old man with a 28-year history of type 2 diabetes, the allergic reactions appeared to be variable in size and duration [68]. Three months after starting CSII with insulin lispro there has been no sign of an allergic response with successful reduction in $\mathrm{HbA}_{1 \mathrm{c}}$ levels. In a 43-year-old-man with a 3-year history of type 1 diabetes, a treatment with CSII using insulin lispro was initiated to achieve insulin tolerance because of the increase in the intensity of the local reaction, despite antihistaminic therapy [69]. The allergic reaction immediately disappeared and optimal metabolic control was achieved. In a 31-year-old pregnant woman with gestational diabetes, an allergy to insulin was suspected because of local reactions and confirmed by skin-prick tests [70]. A treatment with CSII and insulin lispro was initiated with an oral antihistaminic drug without local reaction. However, seven weeks after the initiation of such treatment, local reactions reappeared. In a 21 year old woman, uncontrolled type 1 diabetes was observed due to severe cutaneous allergies to insulin resulting in poor compliance to intermittent insulin injections [71]. CSII using insulin lispro was initiated as a low-dose provider for both desensitisation and treatment of diabetes. Boluses were replaced with temporarily increased basal rates over 3 hours starting $1 \mathrm{~h}$ before meals. No local reaction at the insertion site of the catheter or elsewhere was observed anymore and the metabolic control progressively improved. One year later, although intradermal tests remained positive, antihistamine treatment could be stopped and premeal boluses were introduced without reactivating cutaneous allergies. In a 55-year-old woman with type 1 diabetes, an 
allergy to insulin was diagnosed after 6 months of treatment with human insulin. This allergy was confirmed by intradermo-reaction tests for all kinds of insulin, except lispro. A treatment with CSII and insulin lispro was initiated and continued with a good tolerance and a good metabolic control [72]. In an 81-year-old type 2 diabetic patient, hypersensitivity to insulin was described consisting of local skin reaction followed by general urticarian lesions. The skin-prick tests were positive for human and porcine insulin forms and not for insulin aspart. Therefore, a treatment with CSII and insulin aspart was initiated and gave good results on the skin reactions and the metabolic control [61]. In a 25-year-old type 1 diabetic patient, after an initial diagnosis of protamine allergy, an allergy for all kinds of insulin (human, short- and long-acting analogues) was confirmed. A treatment with CSII and insulin aspart associated with oral corticoid therapy was used with success as a desensitisation method [73]. In a 50-year-old type 2 diabetic patient, allergic reactions presented at the local injection site. Intradermal tests confirmed the allergy all kinds of insulin A desensitisation with CSII and insulin lispro was conducted with a real success [57]. In a 60-year-old uncontrolled type 2 diabetic patient, local skin reactions with feeling uncomfortable, sweaty and feverish were observed after all human insulin preparations, including insulin analogues aspart, lispro and glargine. He was commenced on an insulin pump infusing insulin lispro in addition to his oral hypoglycaemic agents and achieved fair control with little or no skin or systemic reaction [63].

\section{Conclusions}

Local hypersensitivity to insulin and lipodystrophies associated with subcutaneous insulin therapy have become rare complications since the generalized use of human insulin Numerous recent observations, mainly published as short case reports, letters to the editor or abstracts, described the positive impact on these complications of using either CSII or short-acting insulin analogues, although controversial data were reported with the latter. Extensive analysis of the literature reveals that combining CSII and the use of a short-acting insulin analogue has been shown to be a valuable strategy in the treatment of localised and generalised hypersensitivity reactions in diabetic patients with insulin allergy. 


\section{REFERENCES}

1. Pickup J, Keen H. Continuous subcutaneous insulin infusion at 25 years : evidence base for the expanding use of insulin pump therapy in type 1 diabetes. Diabetes Care 2002; 25: 593-598.

2. Weissberg-Benchell J, Antisdel-Lomaglio J, Seshadri R. Insulin pump therapy : a meta-analysis. Diabetes Care 2003; 26: $1079-1087$.

3. Colquitt J, Toyle P, Waugh N. Are analogues insulins better than soluble in continuous subcutaneous insulin infusion? Results of a metaanalysis. Diabetic Med. 2003; 20: 863-866.

4. Radermecker RP, Scheen AJ. Continuous subcutaneous insulin infusion with short-acting insulin analogues or human regular insulin : efficacy, safety, quality of life, and cost-effectiveness. Diabetes/Metab Res Rev. 2004; 20: 178-188.

5. Hirsch IB. Insulin analogues. New Engl J Med. 2005; 352: 174-183.

6. Oiknine R, Bernbaum M, Mooradian AD. A critical appraisal of the role of insulin analogues in the management of diabetes mellitus. Drugs 2005; 65: 325-340.

7. Lawrence RD. Local insulin reactions. Lancet 1925; 1: 1125-1126.

8. Vialettes B. L'allergie à l’insuline. Diabete Metab. 1986; 12 : 169-172.

9. Schernthaner G. Immunogenicity and allergenic potential of animal and human insulins. Diabetes Care 1993; 16 (Suppl 3): $155-165$.

10. Paley RG, Tunbridge RE. Dermal reactions to insulin therapy. Diabetes 1952; 1: 22-27.

11. Arkins JA, Engoring NH, Lennon E. The incidence of skin reactivity to insulin in diabetic patients. J Allergy 1962; 33: 69-72.

12. Patterson R, Roberts M, Grammer LC. Insulin allergy; re-evaluation after two decades. Ann Allergy 1990; 64: 459-462.

13. Grammer LC. Immunologic reaction to insulin and other proteins. Immunol Allergy Clin North Am. 1998; 18: 809-816.

14. Richardson T, Kerr D. Skin-related complications of insulin therapy. Epidemiology and emerging management strategies. Am J Clin Dermatol. 2003; 4: 661-667.

15. Sola-Gazagnes A, Pecquet C. Allergie à l’insuline en 2003. Journées de Diabétologie de l’Hôtel Dieu, Flammarion Médecine-Sciences, Paris, 2004, 161-179.

16. Ratner RE, Phillips TM, Steiner M. Persistent cutaneous insulin allergy resulting from high-molecular-weight insulin aggregates. Diabetes 1990; 39: 728-833.

17. Brange J, Owens DR, Kang S, Volund A. Monomeric insulins and their experimental and clinical implications. Diabetes Care 1990; 13: 923-954.

18. Ottesen JL, Nilsson P, Jami J, et al. The potential immunogenicity of human insulin and insulin analogues evaluated in a transgene mouse model. Diabetologia 1994; 37: 1178-1185.

19. JiXiong X, Jianying L, Yulan C, Huixian C. The human insulin analog aspart can induce insulin allergy. Diabetes Care 2004; 27: 20842085. 
20. Radermecker RP, Scheen AJ. Treatment of allergy to insulin using continuous subcutaneous insulin infusion with short-acting insulin analogues. Infusystems International 2004, 3: 1-5.

21. Lepore M, Pampanelli S, Fanelli C, et al. Pharmacokinetics and pharmacodynamics of subcutaneous injection of long-acting human insulin analog glargine, NPH insulin, and ultralente human insulin and continuous subcutaneous infusion of insulin lispro. Diabetes 2000; 49: 21422148.

22. Doyle EA, Weinzimer SA, Steffen AT, et al. A randomized, prospective trial comparing the efficacy of continuous subcutaneous insulin infusion with multiple daily injections using insulin glargine. Diabetes Care 2004; 27: 1554-1558.

23. Kahn CR, Rosenthal AS. Immunologic reactions to insulin: insulin allergy, insulin resistance, and the autoimmune insulin syndrome. Diabetes Care 1979; 2: 283-295.

24. Grammer L. Insulin allergy. Clin Rev Allergy 1986; 4: 189-200.

25. Messaad D, Outtas O, Demoly P. Hypersensibilité aux insulines. Presse Med. 2004; 33 : 631-638.

26. Bodtger U, Wittrup M. A rational clinical approach to suspected insulin allergy: status after five years and 22 cases. Diabet Med. 2005; 22: 102-106.

27. De Shazo RD, Boehm TM, Kumar D, Galloway JA. Dermal hypersensitivity reactions to insulin: correlations of three patterns to their histopathology. J Allergy Clin Immunol. 1982; 69: 229-237.

28. Silva MER, Mendes MJM, Ursich MJM, et al. Human insulin allergy-immediate and late type III reactions in a long-standing IDDM patient. Diabetes Res Clin Pract. 1997; 36: 67-70.

29. Katahira M, Hara I, Nishizaki T. Insulin allergy decreased by Humulin S (Humulin R) and not by insulin aspart or Actrapid Penfill (Penfill R). Diabetic Med. 2005; 22: 1454-1459.

30. Lee A-Y, Chey W-Y, Choi J, Jeon J-S. Insulin-induced drug eruptions and reliability of skin tests. Acta Derm Venereol. 2002; 82: 114117.

31. Primeau M-N, Adkinson NF Jr, Hamilton RG. Natural rubber pharmaceutical vial closures release latex allergens that produce skin reactions. J Allergy Clin Immunol. 2001; 107: 958-962.

32. Shojaei AR, Haas DA. Local anesthetic cartridges and latex allergy : a literature review. J Can Dent Assoc. 2002; 68: 622-626.

33. Roest MA, Shaw S, Orton DI. Insulin-injection-site reactions associated with type 1 latex allergy. $N$ Engl J Med. 2003; 348: 265-266.

34. Lougheed W, Albisser AM, Martindale HM, Chow JC, Clement JR. Physical stability of insulin formulations. Diabetes 1983; 32: 424432.

35. Chantelau E, Lange G, Gasthaus M, Boxberger M, Berger M. Interaction between plastic catheter tubings and regular insulin preparations used for continuous subcutaneous insulin-infusion therapy. Diabetes Care 1987; 10: 348-351.

36. Melberg SG, Havelund S, Villumsen J, Brange J. Insulin compatibility with polymer materials used in external pump infusion systems. Diabet Med 1988; 5: 243-247. 
37. Radermecker RP, Piérard GE, Scheen AJ. Lipodystrophy reactions to insulin : effects of continuous insulin infusion and new insulin analogues. Submitted.

38. Grant W, deShazo RD, Frentz J. Use of low-dose continuous corticosteroid infusion to facilitate insulin pump use in local insulin hypersensitivity. Diabetes Care 1986; 9: 318-319.

39. Gin H, Aubertin J. Generalized allergy due to zinc and protamine in insulin preparation treated with insulin pump. Diabetes Care 1987; 10: 789-790.

40. Valentini U, Cimino A, Rocca L, Pelizzari R, Rotondi A, Tosoni C. CSII in management of insulin allergy. Diabetes Care 1988; 11: 978.

41. Nagai T, Nagai Y, Tomizawa T, Mori M. Immediate-type human insulin allergy successfully treated by continuous subcutaneous insulin infusion. Intern Med. 1997; 36: 575-578.

42. Fineberg NS, Fineberg SG, Anderson JH, Birkett MA, Gibson RG, Hufferd S. Immunologic effects of insulin lispro [(Lys (B28), Pro (B29) human insulin)] in IDDM and NIDDM patients previously treated with insulin. Diabetes 1996; 45: 1750-1754.

43. Fineberg SE, Huang J, Brunelle R, Gulliya KS, Anderson JH Jr. Effect of long-term exposure to insulin lispro on the induction of antibody response in patients with type 1 or type 2 diabetes. Diabetes Care 2003; 26: 89-96.

44. Lindholm A, Jensen LB, Home PD, Raskin P, Boehm BO, Rastam J. Immune responses to insulin aspart and biphasic insulin aspart in people with type 1 and type 2 diabetes. Diabetes Care 2002; 25: 876-882.

45. Kumar D. Lispro analog for treatment of generalized allergy to human insulin. Diabetes Care 1997; 20: 1357-1359.

46. Abraham MR, Al-Sharafi BA, Saavedra GA, Khardori R. Lispro in the treatment of insulin allergy. Diabetes Care 1999; $22: 1916-1917$.

47. Lluch-Bernal M, Fernandez M, Herrera-Pombo JL, Sastre J. Insulin lispro, an alternative in insulin hypersensitivity. Allergy 1999; 54: 186-187.

48. Panczei P, Hosszufalusi N, Horvath MM, Horvath A. Advantage of insulin lispro in suspected insulin allergy. Allergy 2000; 55: 418-9.

49. Adachi A, Fukunaga A, Horikawa T. A case of human insulin allergy induced by short-acting and intermediate-acting insulin but not by long-acting insulin. Int J Dermatol. 2004; 43: 597-599.

50. Airaghi L, Lorini M, Tedeschi A. The insulin analog aspart : a safe alternative in insulin allergy. Diabetes Care 2001; $24: 2000$.

51. Yasuda H, Nagata M, Moriyama H, et al. Human insulin analog insulin aspart does not cause insulin allergy. Diabetes Care 2001; 24: 2008-2009.

52. Kara C, Kutlu AO, Evliyaoglu O, Bilgili H, Yildirim N. Successful treatment of insulin allergy in a 1-year-old infant with neonatal diabetes by lispro and glargine insulin. Diabetes Care 2005; 28: 983-984.

53. Hermoso F, Vazquez M, Chaves G, Reviriego J, Andion R. Generalized allergy to human insulin treated with insulin lispro (Abstract). Diabetologia 1997; 40 (Suppl 1): A349.

54. Barranco R, Herrero T, Tomero P, et al. Systemic allergic reaction by a human insulin analog. Allergy 2003; 58: 536. 
55. Yokoyama H, Fukumoto S, Koyama H, Emoto M, Kitagawa Y, Nishizawa Y. Insulin allergy; desensitization with crystalline zincinsulin and steroid tapering. Diab Res Clin Pract. 2003; 61: 161-166.

56. Mizuhashi S, Nakamura K, Mori Y, Noda M, Nakanishi K. Insulin allergy and immunologic insulin resistance caused by interleukin-6 in a patient with lung cancer. Diabetes Care 2006; 29: 1711-1712.

57. Castera V, Dutour-Meyer A, Koeppel M, Petijean C, Darmon P. Systemic allergy to human insulin and its rapid and long acting analogs : successful treatment by continuous subcutaneous insulin lispro infusion. Diabetes Metab. 2005; 31: 391-400.

58. Takata H, Kumon Y, Osaki F, et al. The human insulin analogue aspart is not the almighty solution for insulin allergy. Diabetes Care 2003; 26: 253-254.

59. Frigerio C, Aubry M, Gomez F, et al. Desensitization-resistant insulin allergy. Allergy 1997; 52: 238-239.

60. Moriyama H, Nagata M, Fujihira K, et al. Treatment with human analog (Gly ${ }^{\text {A21 }}$, Arg $^{\mathrm{B} 31}$, $\mathrm{Arg}^{\mathrm{B} 32}$ ) insulin glargine (HOE901) resolves a generalized allergy to human insulin in type 1 diabetes. Diabetes Care 2001; 24: 411-412.

61. Durand-Gonzalez KN, Guillausseau N, Pecquet C, Gayno JP. Glargine insulin is not an alternative in insulin allergy. Diabetes Care 2003; 26: 2216.

62. Vernassière C, Tréchot P, Guerci B, Commun N, Schmutz JL, Barbaud A. Deux premiers cas de sensibilisation retardée aux insulines humaines recombinantes modifiées (Abstract). Ann Dermatol Venereol. 2004; 13: P1.

63. Moyes V, Driver R, Croom A, Mirakian R, Chowdhury TA. Insulin allergy in a patient with Type 2 diabetes successfully treated with continuous subcutaneous insulin infusion. Diabet Med. 2006; 23: 204-206.

64. Darmon P, Castera V, Koeppel M-C, Petitjean C, Dutour A. Type III allergy to insulin detemir. Diabetes Care 2005; $28: 2980$.

65. Lougheed WD, Zinman B, Strack TR, et al. Stability of insulin Lispro in insulin infusion systems. Diabetes Care 1997; 20: 1061-1065.

66. Defelippis MR, Bell MA, Heyob JA, Storms SM. In vitro stability of insulin lispro in continuous subcutaneous insulin infusion. Diabetes Technol Ther. 2006; 8: 358-368.

67. Eapen SS, Connor EL, Gern JE. Insulin desensitisation with insulin lispro and an insulin pump in a 5-year-old child. Ann Allergy Asthma Immunol. 2000; 85: 395-397.

68. Pratt EJ, Miles P, Kerr D. Localized insulin allergy treated with continuous subcutaneous insulin. Diabetic Med 2001; 18 : 514-516.

69. Näf S, Esmatjes E, Recasens M, et al. Continuous subcutaneous insulin infusion to resolve an allergy to human insulin. Diabetes Care 2002; 25: 634-635.

70. Durand-Gonzalez KN, Guillausseau N, Anciaux ML, Hentschel V, Gayno JP. Allergy to insulin in a woman with gestational diabetes mellitus : transient efficiency of continuous subcutaneous insulin lispro infusion. Diabetes Metab. 2003; 29: 432-434.

71. Sola-Gazagnes A, Pecquet C, Radermecker R, et al. Successful treatment of insulin allergy in a type 1 diabetic patient by means of constant subcutaneous pump infusion of insulin. Diabetes Care 2003; 26: 2961-2962.

72. Imiela A, Tavernier J-Y, Carotte-Lefebvre I, Deverny F, Delaporte E, Lamblin C. Allergie à l'insuline humaine recombinante : à propos de 3 cas avec manifestations immédiates généralisées. Rev Franc All Immunol Clin. 2003; 43: 165-169. 
73. Matheu V, Perez E, Hernandez M, et al. Insulin allergy and resistance successfully treated by desensitisation with Aspart insulin. Clin Mol Allergy 2005; 3: 16 doi:10.1186/1476-7961-3-16.

\section{Acknowledgements}

No sources of funding were used to assist in the preparation of this review. The authors have no conflicts of interest that are directly relevant to the content of this review.

Figure 1 : Immunological reactions to insulin (adapted from reference 23).

Table 1 : Brief description of ten clinical cases showing positive effects of continuous subcutaneous infusion (CSII) of a short-acting insulin analogue in diabetic patients presenting insulin allergy when on conventional therapy.

\begin{tabular}{|c|c|c|c|c|c|c|c|c|}
\hline References & $\begin{array}{c}\text { Age } \\
\text { (years) }\end{array}$ & Diabetes & $\begin{array}{c}\text { Insulin } \\
\text { therapy } \\
\text { (months) }\end{array}$ & $\begin{array}{l}\text { Insulin } \\
\text { type }\end{array}$ & $\begin{array}{c}\text { Hypersensitivity } \\
\text { reaction }\end{array}$ & RAST & Skin tests & $\begin{array}{l}\text { Insulin used } \\
\text { in pump }\end{array}$ \\
\hline $\begin{array}{c}\text { Eapen et al } \\
2000(67)\end{array}$ & 5 & Type 1 & 36 & $\begin{array}{l}\text { Human } \\
\text { Porcine }\end{array}$ & $\begin{array}{l}\text { Local } \\
\text { Rash } \\
\text { (Type1) }\end{array}$ & Latex - & $\begin{array}{c}\mathrm{NPH}+ \\
\text { Regular }+\end{array}$ & Lispro \\
\hline $\begin{array}{l}\text { Pratt et al } \\
2001(68)\end{array}$ & 79 & Type 2 & 2 & $\begin{array}{l}\text { Human } \\
\text { Bovine } \\
\text { Porcine } \\
\text { Lispro }\end{array}$ & $\begin{array}{c}\text { Local } \\
\text { (Type III) }\end{array}$ & $\begin{array}{l}\text { Bovine + } \\
\text { Porcine + } \\
\text { Human + }\end{array}$ & 0 & Lispro \\
\hline $\begin{array}{l}\text { Näf et al } \\
2002 \text { (69) }\end{array}$ & 43 & Type 1 & 1 & $\begin{array}{c}\text { Human } \\
\text { Lispro }\end{array}$ & $\begin{array}{c}\text { Local } \\
\text { Then systemic } \\
\text { (Type I) }\end{array}$ & Human + & $\begin{array}{c}\text { Human + } \\
\text { Lispro + } \\
\text { Additives - } \\
\end{array}$ & Lispro \\
\hline $\begin{array}{c}\text { Durand- } \\
\text { Gonzales et al } \\
2003(70)\end{array}$ & 31 & Gestational & 0.5 & Human & $\begin{array}{c}\text { Local } \\
\text { (Type I) }\end{array}$ & Human + & $\begin{array}{c}\text { Human + } \\
\text { Porcine + } \\
\text { Additives - }\end{array}$ & Lispro \\
\hline
\end{tabular}




\begin{tabular}{|c|c|c|c|c|c|c|c|c|}
\hline $\begin{array}{c}\text { Sola-Gazagnes } \\
\text { et al } \\
2003(71) \\
\end{array}$ & 21 & Type 1 & 4 & $\begin{array}{l}\text { Human } \\
\text { Lispro }\end{array}$ & $\begin{array}{c}\text { Local } \\
\text { (Type I) }\end{array}$ & 0 & $\begin{array}{l}\text { Animal + } \\
\text { Human + } \\
\text { Porcine + }\end{array}$ & Lispro \\
\hline $\begin{array}{l}\text { Imiela et al } \\
2003(72)\end{array}$ & 55 & Type 1 & 72 & Human & $\begin{array}{c}\text { Local } \\
\text { Then systemic } \\
\text { (Type I) }\end{array}$ & 0 & $\begin{array}{c}\text { Human + } \\
\text { NPH + } \\
\text { Regular + } \\
\text { Zinc + } \\
\end{array}$ & Lispro \\
\hline $\begin{array}{c}\text { Durand- } \\
\text { Gonzales et al } \\
2003(61) \\
\end{array}$ & 81 & Type 2 & $<12$ & Human & $\begin{array}{c}\text { Local } \\
\text { Then systemic } \\
\text { (Type I) }\end{array}$ & 0 & $\begin{array}{c}\text { Porcine + } \\
\text { Human }+ \\
\text { Lispro }+ \\
\end{array}$ & Aspart \\
\hline $\begin{array}{c}\text { Matheu et al } \\
2005 \text { (73) }\end{array}$ & 25 & Type 1 & 24 & $\begin{array}{l}\text { Human } \\
\text { Lispro }\end{array}$ & $\begin{array}{c}\text { Local } \\
\text { (Type 1) }\end{array}$ & $\begin{array}{c}\text { Protamine }+ \\
\text { Bovine }+ \\
\text { Porcine }+ \\
\text { Human }+\end{array}$ & $\begin{array}{c}\text { Protamine + } \\
\text { Regular + } \\
\text { Aspart + } \\
\text { Lispro + } \\
\text { Glargine + } \\
\end{array}$ & Aspart \\
\hline $\begin{array}{c}\text { Castera et al } \\
2005(57)\end{array}$ & 50 & Type 2 & 6 & $\begin{array}{l}\text { Lispro } \\
\text { Human }\end{array}$ & $\begin{array}{c}\text { Local } \\
\text { Then systemic } \\
\text { (Type I) }\end{array}$ & 0 & $\begin{array}{c}\text { Porcine + } \\
\text { Human + } \\
\text { Protamine + } \\
\text { Lispro + } \\
\text { Aspart + } \\
\text { Glargine + }\end{array}$ & Lispro \\
\hline $\begin{array}{l}\text { Moyes et al } \\
2006(63)\end{array}$ & 60 & Type 2 & $<12$ & $\begin{array}{l}\text { Human } \\
\text { Lispro } \\
\text { Aspart } \\
\text { Glargine }\end{array}$ & $\begin{array}{c}\text { Local } \\
\text { Then systemic } \\
\text { (Type I) }\end{array}$ & 0 & $\begin{array}{c}\text { Human + } \\
\text { Lispro + } \\
\text { Aspart + }\end{array}$ & Lispro \\
\hline
\end{tabular}

RAST: Reactive Allergen Specific Test 0 : not realised or not available -: negative test

+ : positive test 